\title{
Article
}

\section{Beyond technofix: Thinking with Epimetheus in the anthropocene}

\author{
Benoit Dillet $^{\mathrm{a}, *}$ and Sophia Hatzisavvidou ${ }^{\mathrm{b}}$ \\ ${ }^{a}$ University of Bath, Bath BA2 7AY, UK. \\ b.dillet@bath.ac.uk \\ s.hatzisavvidou@bath.ac.uk \\ *Corresponding author.
}

\begin{abstract}
The Prometheus myth has long now provided inspiration for those who envision solutions to environmental issues. Prometheus is the figure par excellence of human forethought and progress in the anthropocene. In this article, we introduce the concept of ambient Prometheanism to describe the way of thinking that foregrounds foresight and anticipation and advances technological solutions developed by capital and energy-intensive projects. We question this stance, arguing that ambient Prometheanism, with its emphasis on technofix, leads to the economisation and depoliticisation of planetary environmental issues. Following Bernard Stiegler, we recover from the myth the figure of Epimetheus, Prometheus' brother, as well as his associated faculty, epimetheia to theorise what we call an 'Epimethean politics'. Thinking the anthropocene from the perspective of ambient Prometheanism and Epimetheanism means to consider the role of technology in climate politics, and in particular to make the case for the importance of afterthought in face of unintended consequences and accumulated errors. To substantiate our argument, we outline the challenge posed by emerging solutions focussed on technological intensification (geoengineering) and socio-economic acceleration (green growth and accelerationism). An Epimethean politics of the climate requires to use reflexivity as a capacity to anticipate, but also to mobilise epimetheia to account for accidents and past mistakes. Such a politics builds from an alternative conception of technology, one that radically differs from ambient Prometheanism. Finally we read as actualisations of Epimethean politics contemporary eco-political struggles and their imperatives for multispecies living and convivial livelihoods.

Contemporary Political Theory (2022) 21, 351-372. https://doi.org/10.1057/s41296021-00521-w; advance online publication 9 September 2021
\end{abstract}

Keywords: Anthropocene; Epimetheus; Prometheanism; Climate change; Technology

(c) 2021 The Author(s), under exclusive licence to Springer Nature Limited. 1470-8914 Contemporary Political Theory Vol. 21, 3, 351-372

www.palgrave.com/journals 
Global environmental change presents a situation of no-return: far from being simply a challenge to be overcome in the short term, it has opened a new epoch, the anthropocene, in which humans face themselves as a geophysical force. The anthropocene asks us to address the question " what to do" after "having done", (Baranzoni, 2017, p. 44); in other words, it asks us to consider our actions in the afterwardness of rising temperatures and mass species extinctions. Nonetheless, it is anticipation and forethought that have captured the imagination of political leaders, policy makers and many environmentalists (Baskin, 2019).

In this article we argue that this preoccupation with foresight takes the form of a denialism that obscures the role that afterthought plays in the formation of critical responses to the climate crisis. We introduce the concept 'ambient Prometheanism' to capture the pervasive doctrine that advocates humanity's ability to confront the ecological crisis through costly technological interventions fuelled by intensified economisation. As opposed to explicit forms of denialism advanced by figures such as Trump, Bolsonaro, and their ilk (Lockwood, 2018), which rely on the negation of the very existence of climate change, the variety of denialism we outline here calls to solve the climate crisis by ingenious solutions and dominates the discourse of international and national climate policy making and planning and hence its ambient dimension.

The recent fixation with electric cars as an integral aspect of a post-carbon economy is a good example of the ambiesnt Promethean logic. Rather than addressing social, racial and sexual inequalities and suffering produced by financialised capitalism, the craze for electric cars furthers business-as-usual economic practices that update the American way of life. An Epimethean approach to green technologies such as electric cars would entail disrupting the linear timeline inscribed in the widely adopted framework of energy transitions. According to the latter, capitalist economies initially relied on wood, progressing to coal, then to oil and now are entering the next transitional phase of renewable energy. This framework is misleading: humanity has never consumed more coal and oil than today; this framework is based on 'a past that has never existed and a future that remains illusory' (Fressoz, 2021, p. 11). The history of energy is not one of transitions, but one of additions (Fressoz, 2021, p. 7).

The problem with the ambient Promethean doctrine is that it uproots specific technologies and innovations (in our example, electric cars) from their social, economic and historical/energetic contexts, while an Epimethean perspective, as this article will make clear, is informed by epimetheia (afterthought). Therefore, it takes into consideration the demand for environmental justice, namely the redistribution of the ecological and social gains that produced particular technologies.

Ambient Prometheanism gains currency by posing as 'smart', 'green' and 'sustainable', appealing thus to environmentalists who are attracted to technological solutions, innovation and the vision of endless economic growth decoupled 
from natural resources. We propose that ambient Prometheanism is a denialism on two grounds: first it denies the urgency of the problem and defers transformative action to address the causes and social effects, focussing instead solely on its symptoms; second, it denies the possibility of alternative solutions and forsakes the possibility of alternative socio-ecological futures, repressing political ecologies that disrupt the current state of affairs by aspiring to less violent forms of convivial multispecies coexistence. Infused by an implacable techno-optimism, ambient Prometheanism offers a supposedly emancipatory vision that dismisses small-scale transformative action as too slow, irrelevant and backward-looking.

The argument we offer in this article draws on the literature of contemporary political theory as well as of political ecology, science and technology studies, and of political economy, and will be of particular interest to political theorists who turn their attention to the tension between the climate emergency and technology.

The article is organised in three sections. In the first section, we discuss the reception of the myth of Prometheus and Epimetheus in environmental thought. We note that although in the relevant literature Prometheanism is recognised as one of the possible responses to the anthropocene (Dryzek, 2013; Schlosberg, 2016), in fact few thinkers pay attention to the myth in its totality.

Moreover, the term Prometheanism has come to be associated with 'technological solutionism' (Morozov, 2013), and today permeates policy responses to the ecological crisis that reduce it to a neat problem that can be addressed through appropriate technological interventions. Therefore, we return to the myth of Prometheus and Epimetheus in order to expose some of the assumptions made by social and political theorists about technology, but also their lack of attention in using this myth - in particular, the forgetting of Epimetheus (Stiegler, 1998). The first section, then, clarifies the ground upon which we build our critique of Prometheanism and develop our alternative.

The second section offers a nuanced and expanded discussion of ambient Prometheanism, which we define as the doctrine that favours anticipation and foresight (prometheia) and focuses on large-scale commercialised technological solutions. We argue that this way of thinking cuts across ideological positions and permeates mainstream and emergent discourses on the climate crisis, ultimately leading to the economisation and depoliticisation of planetary environmental issues.

To illustrate this claim, we take on the examples of green growth, accelerationism, and geoengineering and show how these manifestations of ambient Prometheanism impede transformative climate action and threaten convivial livelihoods. The critique of technofix (Huesemann and Huesemann, 2011) that accompanies our discussion of ambient

Prometheanism does not spring from anti-modernist, reactionary, technophobic, or conservative dispositions; rather, it seeks to provide reasons for alternative technologies as well as justification of specific modes of living that would be

(c) 2021 The Author(s), under exclusive licence to Springer Nature Limited. 1470-8914 Contemporary 353 Political Theory Vol. 21, 3, 351-372 
eradicated if technofix continues to reign. The climate crisis does not present a binary situation of either withdrawing from technology or accelerating technology with climate optimisation.

To counter this pervasive doctrine, in the final section, we theorise an Epimethean politics. In doing so, the article recuperates the myth of Prometheus and Epimetheus to develop a critique of 'technological solutionism' without collapsing it into a rejection of technology.

We argue that ambient Prometheanism leaves little space for afterthought and reflection on past mistakes and accidents - actions associated with epimetheia. Epimetheia is particularly suitable to inform a politics fit to address the challenges posed by the anthropocene. Indeed, a progressive ecological politics should work and occasionally does work - at expressing an Epimetheanism that counters ambient Prometheanism and inserts into collective imaginary alternative ecopolitical practices and ways of thinking.

By considering Prometheanism in the context of ecological politics, we draw attention to the complex relationship between technology and climate change; by invoking Epimetheanism we seek to expand and deepen our understanding of the form that political responses to the climate crisis take.

To illustrate this point, we discuss actualisations of Epimethean politics, drawing inspiration not only from the ZAD and NoTAV movements in France and Italy but also from the works of Bernard Stiegler, Isabelle Stengers, and Anna Lowenhaupt Tsing. We show that Epimetheanism does not work in opposition to Prometheanism, but by composing with it; they form a composition of tendencies.

The invention of new technologies and alternative ways of using existing technologies has the potential to disrupt existing scenarios. Afterthought, we argue, has a crucial role to play in attempts to politicise global environmental change and weave new political ecologies and futures.

\section{Prometheus in the Anthropocene}

Geologists have officially declared that we live in the anthropocene, a new geological era shaped by human activities. The anthropocene working group (AWG) was created in 2009 to assess our current geological time and in 2016 it recommended to the international geological congress to recognise that the Earth has left the holocene and entered the anthropocene (Carrington, 2016). This proposition, however, is contested due to the complexity and the stakes involved in the study of the trajectory of the Earth system, but also due to lack of consensus in determining a precise start date as well as the birthplace for the anthropocene. It remains a very recent and still evolving object of study for the geological community that often studies epochs spanning millions of years rather than 
thousands or hundreds of years. Nonetheless, the notion of the anthropocene very quickly travelled to academic fields of inquiry beyond geology (Malhi, 2017).

Researchers in the social and human sciences have criticised the notion of the anthropocene for carrying a multitude of assumptions, particularly related to the identity of the anthropos in question but also in relation to the normative claims that this concept encompasses (see especially Bonneuil and Fressoz, 2016; Haraway, 2015; Moore, 2016). Its contested meaning notwithstanding, we find that the anthropocene provides a useful platform to discuss important political questions across disciplines.

For some environmentalists, the advent of the anthropocene provides the opportunity to fulfil the Baconian vision of human mastery on nature. The figure par excellence of this vision is the titan Prometheus who has long been associated with the strand of environmentalism that advocates the deployment of technological solutions on a large scale as the solution to the ecological crisis and expresses unlimited confidence in human ingenuity (Dryzek, 2013; Meyer, 2016).

Inherent to the Promethean vision is a belief in an unlimited human ability to innovate and resolve complex problems, which entails a view of humans as dominating everything else and of nature as an infinite set of resources (Dryzek, 2013, pp. 59-62). Historically, this figure of the ingenious man - always western white heterosexual male - stars in the narrative that tells the story of the enlightenment and the scientific revolutions of the 17th century. In the 1970s and 1980s the logic of Prometheanism infused narratives that emerged as a response to environmentalists' concern about natural scarcity and limits to growth, with some economists (e.g. Beckermann, 1974; Simon, 1981) arguing that nature is characterised by abundance rather than scarcity and that therefore technology and free markets can ultimately safeguard economic growth infinitely and independently of the state of nature.

These narratives remained in public discourse through an ecology of policies, political speeches, and popular writings by figures such as Bjørn Lomborg who advanced ideas and practices congruent with the Promethean worldview. Although a new generation of Prometheans broadened the scope of agency from free markets to governments (Dryzek, 2013, p. 58), ultimately the thrust of Prometheanism confidence in human ingenuity and abundance of nature - remained as the defining element of this doctrine. As Lewis (1992, p. 18) put it, 'in a Promethean environmental future, humans would accentuate the gulf that sets them apart from the rest of the natural world, precisely in order to preserve and enjoy nature at a somewhat distant remove'.

More recently, this was exemplified in the ecomodernist vision of the Breakthrough Institute which took the idea of separating humans from nature to its extreme, proposing that this gap actually needs to be further amplified in order to address the ecological crisis (Asafu-Adjaye et al., 2015). The logic of Prometheanism reinforces the modernist dichotomy between humanity and nature,

(c) 2021 The Author(s), under exclusive licence to Springer Nature Limited. 1470-8914 Contemporary 355 Political Theory Vol. 21, 3, 351-372 
claiming that decoupling human progress from ecological impacts is the necessary condition for addressing the climate crisis. Prometheanism thus offers a feel-good story that celebrates infinite growth through technological advancements without unitended outcomes.

In scrutinising the implications of this logic, we suggest a return to the myth of Prometheus. In turning to mythos, we reject the crude dichotomy between reason and myth that intensified throughout the twentieth century with the process of rationalisation (first analysed by Max Weber) and the development of technoscience (Haraway, 2015; Nordmann, 2011). Indeed, it is this very intensified rationalisation that informs the prioritisation of technofix over political solutions to address the ecological crisis.

As Chiara Bottici (2007, p. 21) notes, the opposition of mythos to logos cannot be found in ancient Greek sources; it is a 'later interpretation of modern rationality in search of its origins'. In turning to mythos, we concur with Bottici $(2007$, p. 22) that myths "elaborated in an epoch of crisis, served not only to provide an identity for the so-called European or Western civilisation, but also to supply an ideological covering for its political expansionism'.

Our critical engagement with Prometheanism does not lie in its rejection as a myth that distorts reality and therefore as a lower form of knowledge; this would entail a continuation of the false opposition between mythos and logos developed in the 20th century for the justification of the superiority of the scientific knowledge produced in the global north over other forms of knowledge. Rather, our return to the myth is influenced by Stiegler's (1998) own retrival of Epimetheus as a figure and epimetheia as a faculty.

We do not aim at recovering some supposed original version of the myth, but at understanding, first, how it has been used as an ideological covering for the pursuit of capital and energy-intensive technoscience and second, how its conceptual richness can illuminate a necessary critique of 'technological solutionism'.

There are various versions of the Prometheus myth, the most common being those recounted by Hesiod, Aeschylus, and Protagoras/Plato. For the purposes of this article, we briefly recount the version of the myth narrated by Protagoras in Plato's (1966) dialogue with the same title.

Following the creation of the world, the two Titans were entrusted with distributing faculties to mortal creatures. Epimetheus persuaded his brother to allow him to do the distribution but being Epimetheus (and so lacking foresight) it was only after completion of the task that he realised that there was no faculty left for the human species. As he was reflecting on his action, Prometheus arrived to inspect his brother's work and found out about his fault.

As Protagoras explains, 'Prometheus, in his perplexity as to what preservation he could devise for man, stole from Hephaestus and Athena wisdom in the arts together with fire' (Plato 321c-d); he then offered them as gifts to humanity, becoming associated with ingenuity, foresight, but also love for the human species. 
We do not aim at providing yet another interpretation of the myth. Rather, following Stiegler (1998) we argue that we need to return to the myth in its entirety by way of taking a step back and looking at the whole story so that we grasp the role of Epimetheus in this narrative. The central element of the myth is the encounter of the two brothers Prometheus and Epimetheus: 'for it is only when the two brothers encounter each other that the temporal movement goes in both directors: Epimetheus looks at the past and understands his mistake, whereas Prometheus looks to the future and understands the solution' (Dorfman, 2017, p. 71).

Stiegler $(1998,2017)$ revisits the myth to show the double logic at play in technology, using his interpretation of the myth with Epimetheus at its centre to develop an original concept of technics and technology as palliative. In his reading, Epimetheus is the 'forgetful', the one who forgets to give human beings qualities, forcing Prometheus to steal fire (technics) from Zeus. This accidental forgetting is overcome by a production of prostheses and artifices: it is following Epimetheus' forgetting that Prometheus can employ foresight to make up for Epimetheus' mistakes.

The invention of these prostheses has considerable consequences for humans, as it is a way for them to extend their potentialities. For Stiegler, humans are characterised by a lack of essence and it is by inventing new prostheses that they palliate for this lack: 'the being of humankind is to be outside itself' (Stiegler, 1998, p. 193). As Stiegler elucidates, the overlooking of the figure of Epimetheus leads philosophers to misunderstand technics: the origin of technics is not found in the figure of Prometheus alone but in the Epimetheus and Prometheus couple.

We propose that it is only by considering together the closely linked prometheia and epimetheia we can fully grasp the stakes of technology amidst the climate crisis. If prometheia is the type of thinking that discovers solutions to the problem at hand, epimetheia is the quality of the intellect which manifests itself after the solution given proves inadequate or has unforeseen ramifications. ${ }^{2}$

There is, then, a difference in how each quality encounters the occasion: prometheia enables its exploitation, whereas epimetheia only returns to it ex posterior, by way of reflecting on it. The figure of Epimetheus brings to our attention the role of accidents and unintended consequences of human devices and plans. As Hans Jonas (1984) explains, the term accidents refers not to problems that emerge due to faults with technology, but to the unforeseen side effects that technology can cause and which become evident only after the use of technological solutions. Similarly for Stiegler (2017), technology and accidentals arrive together, technologies are invented to respond to individual accidents and yet technologies often produce glitches and failures. Thus, we suggest that attending to epimetheia in view of global environmental change can open up a space for considering issues and challenges that unimpeded techno-optimism overlooks.

(c) 2021 The Author(s), under exclusive licence to Springer Nature Limited. 1470-8914 Contemporary 357 Political Theory Vol. 21, 3, 351-372 
One way to understand Prometheanism in the current socio-ecological conjuncture is as a particular vantage point of encountering the reality of the anthropocene. If the anthropocene is the era when humans have become a geological force themselves, then Prometheanism is the way of thinking that endorses the reality of the anthropocene as a challenge that humanity can address through technofix. As we clarify in the next section, although for some of its proponents the anthropocene is seen as an opportunity to advance a communism with a modern outlook, ultimately ambient Promethianism is unfit to escape the grip of unregulated technocapitalism. But importantly, it is also a form of denialism that overlooks transformative action and the question of accidents and unintended consequences opened up by Epimetheus, as it will become clear in the last section.

Although the vision of humanity as a self-conscious maker of its own destiny is imbricated in the idea of modernity, today the Promethean way of thinking goes beyond modernity's project of progress as articulated in the political theory of Proudhon (1972) or Marx (1967). In this ambient Prometheanism - further clarified in more detail in the next section - at stake is the survival of the human edifice, even at the expense of non-human worlds.

Although we draw on Stiegler, we expand his line of argument from faculties (prometheia and epimetheia) to vantage points to consider the global environmental crisis in dynamic terms and therefore as the result of decades of what environmental historians Bonneuil and Fressoz call 'disinhibition', that is, a process of forgetting past mistakes and superseding early warnings. Rather than simply attempting to deconstruct Prometheanism, we argue that recovering epimetheia/prometheia as a composition of tendencies contributes to a political theory of the anthropocene.

We demonstrate this in the final section where we explain how this expanded understanding of human abilities disrupts existing power relations and creates opportunities for politicising global environmental change.

\section{Manifestations of Ambient Prometheanism in the Anthropocene}

Like Prometheanism, the concept of ambient Prometheanism that we introduce here does not refer to a homogenous project or school of thought; to suggest this would be to overlook the many contradictions and divergences that characterise it, both epistemologically and politically. The trajectory of environmental Promethanism, from an anti-environmental stance against arguments for the existence of ecological limits to an environmental doctrine championing free-market economy and technological intensification, is well documented (Dryzek, 2013; Meyer, 2016). Prometheanism is underpinned by 'a theory of human ingenuity, but also a theory of nature's abundance’ (Dryzek, 2013, p. 70). 
We propose the concept ambient Prometheanism to highlight its pervasive nature: today more than ever before, Prometheanism is unbounded. Ambient Promethanism infuses policies, practices, and ideas endorsed and advanced by progressives (Meyer, 2016), reactionaries and climate deniers who turn to technology nonetheless (Hamilton, 2013), accelerationists (Brassier, 2014; Williams and Srnicek, 2014), and techno-communists (Bastani, 2019). Rather than suggesting that these diverse instances of ecological thinking should be lumped together, we offer the term ambient Prometheanism to capture the ubiguity of the faith and trust in prometheia in responses to the climate crisis today.

As a vantage point to encounter the anthropocene, ambient Prometheanism advances a certain disposition towards limits (and the possibility of their transgression), technology (with economic imperative), and time (especially the future). To flesh out this argument, in this section we discuss three instances of ambient Prometheanism: green growth, accelerationism, and geoengineering. As manifestations of ambient Prometheanism, they all lead to the economisation and depoliticisation of global environmental change by attributing a special role to technoscientific capitalism in climate action and by leaving existing destructive power relations (between humans but also between human and non-human species) intact.

The Promethean way of thinking contributed to the de-radicalisation of the environmental movement in the 1980s and the turn to technology not as a point of critique, but as a source of solutions (Neyrat, 2019). This was in turn related to the increasing scientisation of environmental governance (Bäckstrand, 2004): as environmental problems were perceived as being more and more complicated and technical (e.g. acid rain and ozone hole), they had to be 'managed' using highly specialised scientific knowledge.

In policy making, this scientisation of ecological politics took the form of ecological modernisation, a framework that emphasises the compatibility of environmental protection and pursuit of economic development. It is in the context of this particular framework that the first instance of ambient Prometheanism we examine emerged, with social thinkers proposing that environmental problems far from creating challenges to industrialised societies they actually offer opportunities for economic growth and enterpreneurship.

Originally advanced by the environmental leader Van Jones (2009) to link labour with environmental demands, the idea of 'green growth' was updated and adjusted to fit mainstream policy making following the financial crisis of 2007-2009, gaining traction as a way of bridging the need to protect natural resources and stimulate the economy. It is in this updated form that 'green growth' is championed by international organisations such as the World Bank, the IMF, as well as the UN, which adopted it officially in the conference on sustainable development (or Earth summit) in 2012. It is also promoted by most heads of G8 states, who employ the

(c) 2021 The Author(s), under exclusive licence to Springer Nature Limited. 1470-8914 Contemporary 359 Political Theory Vol. 21, 3, 351-372 
idea of 'green growth' to advance neoliberal economic and social policies (Hatzisavvidou, 2020).

It is thus a commonplace in hegemonic discourses on how best to deal with global environmental change. The premise of the argument for 'green growth' is that the problem of 'environmental degradation' can be solved without abandoning the vision of economic growth. The creation of green technologies and green markets is the necessary condition for achieving this double goal. Green growth promises to enable the pursuit of progress (always understood as endless economic growth) without requiring any changes in 'modern' values, ways of living, and patterns of social and economic organisation. Fueled by green energy, the argument goes, green growth represents a paradigm shift with the potential to generate sustainable and equitable relations between environment, economy, and society.

'Green growth' is a form of ambient Prometheanism, in the sense that it denies the existence of natural limits to growth; it affirms technology funded through vast investment as the primary means for addressing global environmental change, relying on the economisation and financialisation of natural resources, ways of knowing, and carbon emissions; and it projects the possibility of a future that can be already anticipated since humanity will have dominated over every other form of life. It thus obscures the political complexities of the anthropocene, reducing action to investment and financial incentivisation.

At the same time, the very concept of green growth is an oxymoron, as the idea assumes that GDP growth can be permanently and absolutely decoupled from resource use and emissions and that it is possible to disconnect economic and social well-being from the use of biophysical resources. Decoupling is at the heart of the 17 sustainable development goals (SDGs) adopted by the UN Environment Programme (UNEP). ${ }^{3}$

However, in reality there is little empirical evidence that such separation is attainable (Hickel and Kallis, 2019). Even if decoupling becomes feasible technologically, the real question will be if economies and societies could be decarbonised fast enough to stay under 1.5 degrees - or within the 'safe operating space for humanity' (Rockström et al., 2009).

Ambient Prometheanism also manifests itself in social and political theories that advocate that accelerating the speed and intensity of production the material platform of capitalism can be repurposed for common ends (Williams and Srnicek, 2014). The result of this 'Promethean politics of maximal mastery over society and its environment' will be a society with less work with freedom and luxury for all through technological innovation and automation (Bastani, 2019).

Accelerationists envision the transgression of the limits of human ingenuity, natural resources, and even biology, facing future with the optimism of those who have absolute knowledge and control over the forces of nature and history. They thus overlook both the political character of the technologies they endorse, as well as the fact that these technologies operate under the firm grip of capital. 
Accelerationists also reject the idea of planetary limits, since this could block opportunities for growth. They hence encounter the global ecological crisis primarily as the opportune time to transgress capitalism and create a system of 'extreme supply' through the deployment of industrial-scale renewable energy systems funded by national energy investment banks (Bastani, 2019).

A third manifestation of ambient Prometheanism is the idea of intentional modification of climate (geoengineering) in order to alleviate the impacts of climate change. International organisations such as the United Nations and World Bank have already integrated arguments for geoengineering into their discourse, diffusing the idea that such interventions in the Earth's climate are possible, viable, and inherently necessary.

The ambient Prometheanism manifested in geoengineering proposals celebrates the human ability to overcome even the most complex problems, which it collapses into a technological challenge that can be addressed if vast amounts of money are pumped into the task. This technological solutionism silences the need for radical change of current social and economic arrangements and instead advocates the need to continue to work more intensively to secure humanity's existence on the planet.

Accutely aware of the impossibility of safely and responsibly deploying geoengineering solutions in the near future (Chatterjee and Huang, 2020), proponents of ambient Prometheanism intentionally overlook the complexity and uncertainty of geoengineering projects, keeping their gaze fixed upon stakeholders' shares and profits and forgetting that our current ecological condition was caused by the same hubris they demonstrate. In this instance of ambient Prometheanism, climate action is deferred for the future, comfortably placed on the shoulders of future generations.

The three instances of ambient Prometheanism discussed briefly in this section differ in their conceptualisation of the political agent most appropriate to drive climate politics in the anthropocene. They also differ in the socio-economic outcomes they advocate. However, they all share a firm belief in the need to transgress any limits that nature may place on human activities, their optimistic faith in technological progress, and their acceptance of an abstract future as the horizon of climate action.

For proponents of ambient Prometheanism, climate action is essentially about the deployment of techno-fixes and 'green' economic measures. What this way of thinking leaves untreated is existing power relations and the necessity to challenge them if a more equitable socio-ecological formation is to be materialised, not in the distant 2050 but hic et nunc. 


\section{Epimethean Politics}

\section{A radical ignorance of the future}

Ambient Prometheanism manifests itself as a way of thinking that is pervasive and ubiquitous in various approaches to the global environmental crisis, from hegemonic ones promoted by international organisations and green enterpreneurs, to insurgent visions espoused by techno-communists. As a way of encountering the antrhopocene, it cuts across ideological positions, diffusing techno-optimism and deferral.

In this last section, we turn to the figure of Epimetheus in order to elucidate a way of thinking that disrupts and challenges the pervasiveness of ambient Prometheanism. Much like Prometheanism which emancipated itself from the myth, it is not sufficient to come back to the original Greek sources to imagine Epimetheanism, as a force that counters Prometheanism.

An Epimethean climate politics is one that addresses the challenge posed by emerging solutions focussed on technological intensification and socio-economic acceleration, such as those discussed in the previous section. To the extent that it a response to an event that is already unfolding, it is a politics of afterthought. Prometheanism and Epimetheanism are not opposites but composites, as it will be become clear.

Our approach is in line with interpretations of the myth offered by other scholars. As Detienne and Vernant (1991, p. 18) remind us, 'Prometheus and Epimetheus represent the two faces of a single figure just as the prometheia of man is simply the other side to his radical ignorance of the future'. We find that this idea of 'radical ignorance of the future' is particularly relevant to the case of global environmental change, the unprecedented character of which means that notwithstanding the ingenious responses that human societies can develop, the outcome of this intensified, technologically mediated engagement between humans and nature is highly uncertain.

The experience of the Covid-19 pandemic can be seen as an actualisation of this radical ignorance of the future and the sudden opening of a 'new normal'. Billions of people participated in this new social experiment in times of local and nation lockdowns: the use of digital technologies to shop for groceries, to teach and learn at schools and universities, to socialise and even to have access to medical advice. Many referred to Covid-19 as a prefiguration of anthropocenic times.

Although by mobilising prometheia proponents of ambient Prometheanism can provide some solutions or a recourse to global environmental challenge, the radical ignorance of the future entails that Epimetheanism also has an important role to play. Epimetheia is the stage of knowledge that becomes relevant in face of overshight and accumulated errors. The domination of ambient Prometheanism and 
hence foresight and anticipation in the public imaginary is so totalising that the other side of the Promethean myth is usually overlooked.

Even though Epimetheus is typically associated with forgetfulness, as Detienne and Vernant note, prometheia is only the other side of this forgetting (epimetheia): it could not work without committing and then recognising the accident.

We propose then that it is more productive to think of prometheia and epimetheia not as polar opposites, but as tendencies that need to be kept together to shed light to the kind of response more pertinent to climate breakdown. Where Prometheanism mainly projects the importance of ingenuity and forethought, Epimetheanism draws our attention to the crucial task of reflection and afterthought by including prometheia. A politics mainly drawing on epimetheia will be erring, posing a technophobia as its core principle.

In the remainder of this article, we clarify the meaning and workings of epimetheia. First, we discuss it along with reflexivity, which other scholars conceive as the capacity to anticipate rather than to think of the consequences of mistakes. We then outline in concrete terms what Epimethean politics looks like by drawing on the debate on the shifting baseline syndrome, as well as recent scholarship by Bonneuil and Fressoz, Stengers, and Tsing. ${ }^{4}$ Finally, we highlight the practical outlook of epimetheia by briefly discussing some political instances of eco-political activism in France and Italy.

\section{Reflexivity and epimetheia}

Political thinkers have attended to the importance of foresight in ecological politics. For instance, Dryzek and Pickering (2019) refer to foresight as an essential aspect of what they call ecological reflexivity. They distance themselves from adaptive governance and adaptive management in public policy that favour a success-andfailure approach for institutions. They note that, given the instability of the Earth system, institutions have to transform themselves, whereas path dependency prevents effective responses to the climate emergency and the threats to biodiversity. Thus they argue that a state shift in institutions is required to 'forestall catastrophic state shifts in the Earth system itself' (Dryzek and Pickering, 2019, p. 151).

Socio-political institutions cannot exist autonomously from their geophysical setting, and ecological politics starts by taking this inseparability into account. In short, their position is in line with the famous slogan: 'System change, not climate change!'

We want to show below that ecological reflexivity is only one element to counter Prometheanism and that Epimethean afterthought can be a way to deepen the scope of reflexivity. Drawing on the work of reflexive modernity theorists such as Ulrich Beck, Anthony Giddens, and Scott Lash, Dryzek and Pickering (2019, p. 18) affirm ecological reflexivity as an approach that 'listens and responds to signals from the

(c) 2021 The Author(s), under exclusive licence to Springer Nature Limited. 1470-8914 Contemporary 363 Political Theory Vol. 21, 3, 351-372 
Earth system, and has the foresight to anticipate potentially catastrophic changes in the system'. As they argue, ecological reflexivity is the primary requirement for institutions in the anthropocene, since this capacity enables questioning core commitments and therefore adjusting to the new geophysical reality and the challenges it creates. Anthropocene institutions are required to embody foresight, namely not just 'a concern for the future effects of current actions and a recognition that what worked in the past will not necessarily work in the future', but also 'a capacity to anticipate human caused state shifts and act before the shift occurs' (Dryzek and Pickering, 2019, pp. 46-47).

Institutionally embedded ecological reflexivity is indeed a necessary condition of a climate politics that is deeply committed to reverting damage done by anthropocene institutions. What we argue more specifically here is that epimetheia helps counter the grand narrative of the anthropocene written by 'anthropocenologists', as Bonneuil and Fressoz call them. As they clarify (2016, p. 74), the problem with this narrative is that it unfolds around 'subjects from the past who did not act deliberately, who were unaware - who once were blind but now can know'. With reflexive modernity or with the anthropocene, humans have suddenly overcome their innocence regarding the social and environmental consequences of progress or modernity.

As Bonneuil and Fressoz (2016, p. 78) rightly note, 'this narrative, "forgetting" the environmental reflexivity of modern societies, tends to depoliticise the ecological issues of the past and thus obstructs understanding of present issues'. In the anthropocene, politics cannot anymore be about 'awareness-raising' since the knowledge and stories about ecological disasters and the end of the world have been around for a long time, the two environmental historians demonstrate. By forgetting the historical processes that generated the anthropocene, those who focus merely on foresight and anticipation - prometheia - leave intact the power relations that the Earth system has been subjected to for centuries.

To put it more simply, reflexivity regarding environmental degradation and injustice has been around for a long time, almost 200 years according to the French historians. Bonneuil and Fressoz (2016, p. 79) pave the way for the importance of epimetheia in making the case for an environmental history that accounts for past actions and mistakes:

Rather than suppressing the environmental reflexivity of the past, we must understand how we entered the Anthropocene despite very consistent warnings, knowledge and opposition, and forge a new and more credible narrative of what has happened to us.

Much like in the Greek tale, Prometheus would not have had the faculty of foresight without the accident, that is the constitutive oversight from Epimetheus. Foresight works after the accident, in the reflexive moment of the afterthought; it 
cannot function by anticipating or preventing the ecological state shifts in a vacuum. ${ }^{5}$

A useful tool through which we can think about the ramifications of oversight and forgetfulness in the anthropocene is the shifting baseline syndrome. Originating in the context of fisheries, it posits that people increasingly adapt to the new situation and forget about past environmental conditions. The syndrome refers to the fishermen's perception of the fauna composition of the seas and the stock size established at the beginning of their career and used as a baseline to judge the evolution of the stock. This results in a gradual acceptance of the loss of fish species (Soga and Gaston, 2018, p. 222).

This syndrome is based on deeply subjective information since it results from lifetime experience of the shifting baseline, and it can be applied to many other contexts. The shifting baseline syndrome 'involves a gradual change in the accepted norms for the condition of the natural environment due to a lack of experience, memory, and/or knowledge of its past condition' (Soga and Gaston, 2018 , p. 222). The baseline of what was habitual continually shifts from generation to generation; as a result, environmental degradation becomes increasingly tolerated.

For instance, Jens-Christian Svenning (2017) uses this concept to think about the extinction of wild megafauna (animal species larger than or equal to forty-five kilograms body mass). In the anthropocene, most large mammals are under threat and this is not directly linked to changes in the climate (since they managed to adapt to other periods of strong climatic stress) but to the reconfiguration of biogeography by humans. This extinction has long-term ecological effects; it is only by taking a long-term ecological perspective that we can imagine 'diverse landscapes that have existed in pasts beyond human memory' (Svenning, 2017, p. G68). The focus on antitipation of technologically benign futures increases tolerance for past ecological degradations, when what is needed is afterthought: pondering what to do after having done.

\section{The multispecies politics of epimetheia}

Even when deemed 'substantivist and proceduralist' (Dryzek and Pickering, 2019, pp. 56-57), institutional change can forget realities of other ontologies and worlds. An Epimethean ecological politics is not only a way to take care of the Earth and non-humans - to develop empathy and enlarged sensibility; rather, it is premised upon a commitment to different modes of existence.

The anthropocene is the geophysical result of the liberal ontology that is worlddestroying - analysed with precision by Jason Moore (2016) as 'capitalocene'. We cannot forget about the destruction of species and forms of life since 'nothing deserves destruction' as Stengers (2018, p. 87) puts it axiomatically. When we

(c) 2021 The Author(s), under exclusive licence to Springer Nature Limited. 1470-8914 Contemporary 365 Political Theory Vol. 21, 3, 351-372 
project ourselves with foresight or with afterthought, we need to account for the imperatives of multispecies living.

Stengers and Tsing have emphasised in their respective work that ecology is a science of relations rather than the study of individual entities. ${ }^{6}$ Hence the emphasis on the construction of worlds (and world-making) is central to political theory and practice in the anthropocene (Dillet 2021). For example, when activists block the construction of large-scale projects, for instance those of Notre-Dame des Landes near Nantes in France or the France-Italy train connection through the Alps, they also oppose the 'world' that these projects will bring into life. For instance, ZAD activists' main slogan was 'Against the airport and its world'.

These activists bring to attention the potential losses that these projects would bring about, thus demonstrating prometheia; but they also demonstrate epimetheia as they draw from the knowledge accumulated through past mistakes. Their practices demand 'the possibility of restitution, a kind of restitution of the land back to the collective' (Ross, 2018, p. xviii). Rather than a reactionary approach to the past and territories, these movements are experimentations in and creations of new ecologies. One could argue that these are small movements compared to the immensity of climate crisis, but they have already had significant victories against states and large corporations.

Several similar movements emerge around the globe today, seeking to replace the existing flows of capital, energy, and power with new systems of community production and consumption. They thus represent a growing disposition and practice which speaks to the demands of climate and environmental justice movements that restructure everyday practices (Schlosberg and Coles, 2015).

These political agents do not merely defend lands and trees. Restitution here needs to be distinguished from ecological restoration. As ZADists defending existing ecologies and territories put it, 'we do not defend nature, but we are nature that defends itself' (Quadruppani, 2018, p. 26). They set up habitations, collective kitchens, libraries but also meetings and workshops, they use different materials and forms with great creativity and joy. They identify their political action as participating in the making of a multispecies ecology, thus pointing to the inseparability of human society and nature. They work at establishing long-lasting multispecies relations but are faced with constant dismantling by the police and the state. As they amass more and more victories, the ZADs in France have grown larger in the last few years, gaining recognition from local communities, politicians, and intellectuals alike.

Central to these practices is the imperative to re-appropriate ways of doing and ways of knowing that are increasingly segmented and made inaccessible. By encouraging monocultures, capitalist production has exhausted social and natural relations, between different species, human and non-humans but also their milieus of existence. Trees and forests, individuals and their myths, as well as soil and atmospheres are no longer entangled; they are part of a landscape of ruins. 
Nonetheless, as Tsing (2015, p. 6) reminds us, these ruined places can still 'be lively despite announcements of their death; abandoned asset fields sometimes yield new multispecies and multicultural life'. Tsing describes the possibility for multispecies living in the ruins of late capitalism by looking at the natural, geological, social and economic history of matsutake mushroom. As she argues, this mushroom can only grow in the ruins of capitalism, in the precarious world; 'precarity is the condition of our time' (Tsing, 2015, p. 20).

Far from justifying the status quo and fetishising ruins, Tsing develops an art of noticing and sensing the new worlds that proliferate in precarity, the invisible or less-than-visible resistance that continues to grow and live. Hence, for Tsing political ecology needs to develop a new concept of nature, nature as a resurgent event, defining resurgence as 'the work of many organisms, negotiating across differences, to forge assemblages of multispecies livability in the midst of disturbance' (Tsing 2017, p. 52). She draws the idea of resurgence from her ethnographic work that examined the dynamic processes of forests; as she says, 'trees are mobile - and thus they can respond to farming' (Tsing, 2017, p. 54). During the holocene, 'farmers cut back forests, but every time farms were abandoned, forests took back the land. Mimicking their post-Ice Age spread, forests kept returning' (Tsing, 2017, p. 54). Tsing's concept of resurgence is precious to our project of imagining an Epimethean politics beyond technofix, as it is a resource to conceive alternative technologies and their corresponding modes of living.

Here we read Tsing with Bonneuil and Fressoz who argue that every epoch has social struggles against specific technologies. For instance, in the 19th century long social struggles took place to protect forests and we can find examples of resistance to specific innovations in the 18th century too, and these were not a total rejection of modernity or progress but critiques that supported the now-forgotten alternative innovations:

This resistance was never against technology as such, but against a particular technology and its ability to crush others, and we need to unfold the spectrum of alternatives that existed at each moment: canals instead of railways; improved oil lamps instead of gas lighting; flexible and quality production instead of mass production; and an artisanal chemistry with expertise in qualities and sources rather than industrial chemistry, etc. (Bonneuil and Fressoz, 2016, p. 261)

Alternative technologies are associated with alternative modes of living. Every technology favours some people over others since it modifies the milieu of social interactions (especially the division of labour, but not only), and 'technological choices need to be made in a more rather than less democratic' way (Eckersley, 2017, p. 989). And as Robyn Eckersley notes, given the tension between the short-

(C) 2021 The Author(s), under exclusive licence to Springer Nature Limited. 1470-8914 Contemporary 367 Political Theory Vol. 21, 3, 351-372 
term electoral cycle (3-5 years) and the long-term Earth system processes, only a radical democracy can account for the entanglements of humans with non-humans.

Resurgence finds itself in between these two temporalities. In this sense, it is not enough to integrate non-humans in liberal democratic parliaments - what Bruno Latour has been proposing for almost thirty years. This only accounts for one dimension of epimetheia: it is a politics that happens after the permanent noninclusion of non-humans but that does not act upon the forgetting itself.

While Prometheanism puts forward grand projects in complete denial of constitutive acts of forgetting, Epimetheanism begins as a remembering of the forgetful. By making space for remembering past mistakes and investigating the ruins - the damages to both humans and non-humans - the possibility of life in capitalist ruins becomes visible. Nature is not something inert but a receptacle of resurgent events. It is not only an enclosed spatial territory that needs to be defended or preserved, but an event that has seen many occurrences and accidents. Nature is historicised since it has been damaged by centuries of extractivist, colonialist, patriachal and capitalist development, but also noticed, cared for and entangled in stories and relationships (Di Chiro, 2019).

This is crucial since it prevents the adoption of a simplistic understanding of nature as static or as being entirely separate from humans. As Soper (2016) notes, nature is separate from humans but every human practice is conditioned by it. By attending more carefully to the relations between humans and non-humans, the 'cross-species relations that make forests possible', we can start imagining our own 'livability in the midst of disturbance' (Tsing, 2017, p. 52). This does not amount to rejecting technological research and progress; it amounts to imagining technologies, but abandoning them when it is impossible to account for their unintended consequences. In other words, it amounts to not forgetting mistakes that have already been made.

\section{Conclusion}

This article proposes the concept of ambient Prometheanism to describe a hegemonic trend in global responses to the climate emergency that focuses on technofix and intense economisations. This stance also has advocates in contemporary political and social theory. Following Stiegler (1998) we demonstrate that by focussing on anticipation and ingenuity, the role played by Epimetheus and the associated faculty of epimetheia (as afterthought or deferred thinking) in the myth is most of the time forgotten. Through its preoccupation with technoscientific solutions prometheia/foresight appears to be forward-looking, concerning the future; paradoxically, though, the actual focus of Prometheanism is the present frequently following the economic imperative and the maximisation of profits. At the same time, because it concerns reflection on past mistakes, epimetheial 
afterthought appears backwardslooking, as if it is about the past; yet it is about the present, with a projection in the future. It manifests in the present, only after having done, aiming to inform planning in the future.

Epimetheia has an important role to play in ecological politics in the anthropocene, not least because it prevents forgetting humanity's role in global environmental change or the inseparability of society/nature. By emphasising the need for decoupling production from natural resources or for accelerating the process of terraformation and the engineering of the Earth, proponents of ambient Prometheanism have made anticipation and planning appear more positive and useful than afterwardsness and deferred thinking.

Considering our radical ignorance of the future, we need epimetheia so that we do not forget past accumulated errors that led to climate breakdown. Epimetheanism is, therefore, the doctrine that gives space for remembering of the forgetful and acting upon this forgetting. It complements and composes with Prometheanism that is the forgetting of the forgetful, in other words, the forgetting of deferred thinking.

Epimetheus' afterthought is helpful to overcome the denialism that we diagnosed at the start of this article. To forge more equitable, convivial multispecies relations, we - a 'we' that is inclusive and invitational - should consider alternatives that exist or try to be born amidst the ruins while transcending existing socio-ecological inequalities.

\section{Acknowledgements}

Sophia Hatzisavvidou has received funding by the Leverhulme Trust under the Early Career Fellowship Scheme (Grant Number ECF 2016-230). A first version of this paper was presented at the University of Brighton (UK) in January 2019 at the conference 'Fascism? Populism? Democracy? Critical Theories in a Global Context' organised by the International Consortium for Critical Theory (ICCT). The authors would like to thank the organisers of the conference, Volkan Çıdam, Mark Devenney, Zeynep Gambetti and Clare Woodford, as well as the participants for their comments. We also thank George Sotiropoulos and Tara Puri for their valuable feedback on earlier versions of the article as well as Andrew Schaap, and the three anonymous reviewers for their critical and detailed suggestions.

\section{About the authors}

Benoit Dillet is lecturer in politics at the University of Bath. He is author The Political Space of Art (with T. Puri), and translator of Bernard Stiegler's Philosophising by Accident: Interviews with Elie During. He has published on ontological politics and the politics of technology.Sophia Hatzisavvidou is a senior lecturer in politics at the University of Bath. She has been awarded a Leverhulme early career fellowship to study the rhetorical evolution of eco-political discourse.

(C) 2021 The Author(s), under exclusive licence to Springer Nature Limited. 1470-8914 Contemporary 369 Political Theory Vol. 21, 3, 351-372 
She is the author of Appearances to Ethos in Political Theory (Rowman and Littlefield) and has published on ecological politics, political rhetoric, and social movements.

\section{Notes}

1. By defining epimetheia as an intellectual faculty we do not oppose it to other types of faculties. The exercise of the intellect (noesis) is interconnected with embodied dispositions and functions. As Massumi (2002, p. 4) explains, what is at stake in attempts to reflect on human experience as the register of affect, sensing, and thinking is the avoidance of 'the Scylla of naive realism or the Charybdis of subjectivism'.

2. SDG 8 'Decent Work and Economic Growth' pledges to 'improve progressively, through 2030, global resource efficiency in consumption and production and endeavour to decouple economic growth from environmental degradation, in accordance with the 10-year framework of programmes on sustainable consumption and production, with developed countries taking the lead'.

3. These authors build on the traditions of ecofeminism and environmental justice which examined and challenged with precision the environmental inequalities produced by environmental planning, ecological degradation and the extractivist logic of the Western liberal ontology. Here we can point to the tendency in green political theory to forget the tradition of ecofeminism (MacGregor, 2020). Other authors have developed really powerful frameworks that capture the intersectional complexities of environmental inequalities; see for example the recent work of Giovanna Di Chiaro (2020) to design an intersectional environmental justice. We would like to thank one of the anonymous referees for flagging this point.

4. In The Age of Disruption, Stiegler (2019, pp. 124-129) reads Bonneuil and Fressoz's work on dishinbition critically, for lacking the possibility to problematise the 'phase-shift' that takes place between individual and social processes of individuation and technical individuation. He reads their work as defeatist since they call to learn to live in the anthropocene, thus joining critical voices against Harraway's call to stay with the trouble and Tsing's call to follow nature's resurgence. Surprisingly Stiegler did not see the parallel with his work on epimetheia and prometheia and Bonneuil and Fressoz; perhaps he would have expanded on this difference in the future works that he announced but could not complete (in particular the second volume of Automatic Society).

5. Michael Uhall (2021) has recently developed a new theory of the 'ecologically conditioned subject', while others have discussed the possibility of a multispecies justice (Celermajer et al., 2020).

\section{References}

Baranzoni, S. (2017) Anthropocenic times: Stratigraphy of a passage. Azimuth 9: 43-60.

Baskin, J. (2019) Geoengineering, the Anthropocene and the End of Nature. Palgrave: Basingstoke.

Bastani, A. (2019) Fully Automated Luxury Communism: A Manifesto. Verso: London.

Beckermann, W. (1974) In Defence of Economic Growth. Cape: London.

Bonneuil, F. and Fressoz, J.B. (2016) The Shock of the Anthropocene: The Earth, History and Us. Verso: London.

Bottici, C. (2007) The Philosophy of Political Myth. Cambridge University Press: Cambridge. 
Brassier, R. (2014) Prometheanism and its critics. In R. Mackay and A. Avenessian (eds.) Accelerate: The Accelerationist Reader. Urbanomic: Falmouth.

Breakthrough Institute. (2015) An Ecomodernist Manifesto. Breakthrough Institute.

Carrington, C. (2016) The Anthropocene epoch: Scientists declare dawn of human-influenced age, The Guardian, 29th August 2016.

Castoriadis, C. (2007) Aeschylian anthropogony and sophoclean self-creation of anthropos. In: Figures of the Thinkable. Stanford: Stanford University Press.

Celermajer, D., Chatterjee, S., Cochrane, A., Fishel, S., Neimanis, A., O’Brien, A., et al. (2020) Justice through a multispecies lens. Contemporary Political Theory 19: 475-512.

Detienne, M. and Vernant, J.P. (1991) Cunning Intelligence in Greek Culture and Society. Chicago: Chicago University Press.

Di Chiro, G. (2020) Mobilizing 'intersectionality' in environmental justice research and action in a time of crisis. In D. Coolsaet (ed.) Environmental Justice: Key Issues. London: Routledge.

Di Chiro, G. (2019) Care not growth: Imagining a subsistence economy for all. The British Journal of Politics and International Relations 21(2): 303-311.

Dryzek, J.S. (2013) The The Politics of the Earth: Environmental Discourses (Oxford: Oxford University Press, 2005), 261 pp. US \$35.00 paper, ISBN 0-19-927739-7 . Oxford: Oxford University Press.

Dryzek, J.S. and Pickering, J. (2019) The Politics of the Anthropocene. Oxford University Press: Oxford.

Eckersley, R. (2017) Geopolitan democracy in the anthropocene. Political Studies 65: 983-999.

Fressoz, J.-B. (2021) Pour une histoire des symbioses énergétiques et matérielles. Annales Des Mines Responsabilitié \& Environnement 101: 7-11.

Hamilton, C. (2013) Earthmasters: The Dawn of the Age of Climate Engineering. New Haven, CT: Yale University Press.

Haraway, D. (2015) Anthropocene, capitalocene, plantationocene, chthulucene: making kin. Environmental Humanities 6: 159-165.

Hatzisavvidou, S. (2020) Inventing the environmental state: neoliberal common sense and the limits to transformation. Environmental Politics: beyond the Environmental State? the Political Prospects of a Sustainability Transformation 29: 96-114.

Hickel, J. and Kallis, G. (2019) Is green growth possible? New Political Economy 25: 469-486.

Huesemann, M. and Huesemann, J. (2011) Technofix: Why Technology Won't Save Us or the Environment. Gabriola Island, BC: New Society Publishers.

Jonas, H. (1984) The Imperative of Responsibility. Chicago, IL: University of Chicago Press.

Kirk, G.S. (1974) The Nature of Greek Myths. London: Penguin.

Lewis, M.J. (1992) Green Delusions: An Environmentalist Critique of Radical Environmentalism. Durham: Duke University Press.

Lockwood, M. (2018) Right-wing populism and the climate change agenda: Exploring the linkages. Environmental Politics 27: 712-732.

Malhi, Y. (2017) The concept of the anthropocene. Annual Review of Environment and Resources 42: 77-104.

Marx, K. (1967) The difference between the democritean and epicurean philosophy of nature. In N.D. Livergood (ed.) Activity in Marx's Philosophy. The Hague: Martinus Nijhuff.

MacGregor, S. (2020) Making matter great again? Ecofeminism, new materialism and the everyday turn in environmental politics. Environmental Politics 30(1-2): 41-60.

Meyer, W.B. (2016) The Progressive Environmental Prometheans: Left-Wing Heralds of a "Good Anthropocene.” Basingstoke: Palgrave.

Moore, J.W. (ed.) (2016) Anthropocene or Capitalocene?: Nature, History, and the Crisis of Capitalism. Oakland, CA: PM Press.

Morozov, E. (2013) To Save Everything, Click Here: The Folly of Technological Solutionism. Philadephia, PA: PublicAffairs. 
Nordmann, A. (2011) The age of technoscience. In A. Nordmann, H. Radder and G. Scheimann (eds.) Science Transformed: Debating Claims of an Epochal Break. Pittsburgh: University of Pittsburgh Press.

Plato. (1966) Protagoras. London: Penguin.

Proudhon, P.J. (1972) System of Economical Contradictions. New York: Arno Press.

Quadruppani, S. (2018) Le Monde des grands projets et ses ennemis. Paris: La Découverte.

Rockström, J., Steffen, W., Noone, K., Persson, A., Chapin, F.S., 3rd., Lambin, E.F., et al. (2009) A safe operating space for humanity. Nature 461: 472-475.

Ross, K. (2018) Preface: Making a territory. In: Mauvaise Troupe Collective (ed.), The Zad and NoTAV: Territorial Struggles and the Making of a New Political Intelligence. London: Verso.

Schlosberg, D. and Coles, R. (2015) The new environmentalism of everyday life: Sustainability, material flows and movements. Contemporary Political Theory 15: 160-181.

Simon, J.L. (1981) The Ultimate Resource. Princeton, NJ: Princeton University Press.

Soga, M. and Gaston, K.J. (2018) Shifting baseline syndrome: Causes, consequences, and implications. Frontiers in Ecology and the Environment 16: 222-230.

Soper, K. (2016) Neither the "simple backward look" nor the "simple progressive thrust": Ecocriticism and the politics of prosperity. In M. Midweek, G. Rippl and H. Zapf (eds.) Handbook of Ecocriticism and Cultural Ecology. Berlin: de Gruyter.

Stengers, I. (2018) The challenge of ontological politics. In M. de la Cadena and M. Blaser (eds.) A World of Many Worlds. Durham: Duke University Press.

Stiegler, B. (1998) Technics and Time, Vol. 1: The Fault of Epimetheus. Stanford: Stanford University Press.

Stiegler, B. (2017) Philosophising by Accident: Interviews with Elie During. Edinburgh: Edinburgh University Press.

Svenning, J.-C. (2017) Future megafaunas: A historical perspective on the potential for a wilder anthropocene. In A.L. Tsing, H. Swanson, E. Gan and N. Bubandt (eds.) Arts of Living on a Damaged Planet. Minneapolis: University of Minnesota Press.

Tsing, A.L. (2015) The Mushroom at the End of the World: On the Possibility of Life in Capitalist Ruins. Princeton: Princeton University Press.

Tsing, A.L. (2017) A threat to holocene resurgence is a threat to livability. In M. Brightman and J. Lewis (eds.) The Anthropology of Sustainability. Basingstoke: Palgrave.

Uhall, M. (2021) Companion ecologies: A new theory of the subject Contemporary Political Theory, online first.

Williams, A. and Srnicek, N. (2014) Accelerate: Manifesto for an accelerationist politics. In R. Mackay and A. Avanessian (eds.) Accelerate. Falmouth: Urbanomic.

Publisher's Note Springer Nature remains neutral with regard to jurisdictional claims in published maps and institutional affiliations. 